\title{
Penatalaksanaan Anestesi pada Perdarahan Intraserebral dengan Hidrosefalus dan Diabetes Melitus
}

\author{
Djefri F Longdong*), Iwan Abdul Rachman**), Dewi Yulianti Bisri" ${ }^{* * *}$, Sudadi ${ }^{* * *}$, Siti Chasnak Saleh $\left.{ }^{* * * *}\right)$ \\ ${ }^{*}$ Departemen Anestesiologi Rumah Sakit Angkatan Darat Jakarta, ${ }^{* *}$ Departemen Anestesiologi dan Terapi Intensif \\ Fakultas Kedokteran Universitas Padjadjaran, RSUP Dr Hasan Sadikin Bandung, ${ }^{* * *}$ Departemen Anestesiologi \\ dan Terapi Intensif Fakultas Kedokteran Universitas Gadjah Mada-RSUP Dr Sardjito Yogyakarta, ${ }^{* * * *}$ Departemen \\ Anestesiologi dan Terapi Intensif Fakultas Kedokteran Universitas Airlangga-RSUD Dr Soetomo Surabaya
}

\begin{abstract}
Abstrak
Perdarahan Intraserebral (PIS) adalah ekstravasasi darah yang masuk kedalam parenkim otak, yang dapat berkembang ke ruang ventrikel dan subarahnoid, terjadi spontan dan bukan disebabkan oleh trauma (non traumatis) dan merupakan salah satu penyebab tersering pada pasien yang dirawat di unit perawatan kritis saraf. Kejadian PIS 10-15\% dari semua stroke dengan tingkat angka kematian tertinggi dari subtipe stroke dan diperkirakan $60 \%$ tidak bertahan lebih dari satu tahun. Kasus: Laki-laki 57 tahun, datang dengan keluhan penurunan kesadaran yang terjadi pada saat mau makan. Pada pemeriksaan didapatkan kesadaran GCS E1M4V1 dengan hemodinamik stabil, dan terdapat hemiplegi sinistra. Pasien diintubasi dan memakai ventilator di ruangan Instalasi Gawat Darurat Disaster sambil menunggu hasil skrining Covid 19 dengan swab polymerase chain reaction (PCR). Pada CT-scan ditemukan adanya PIS 48,93 cc di basal ganglia, capsula eksterna sampai periventrikel lateralis kanan, terjadi distorsi midline sejauh $1 \mathrm{~cm}$ ke kiri. Ventrikulomegali disertai perdarahan intraventrikel yang mengisi ventrikel lateralis kanan dan kiri, ventrikel III dan IV. Laboratorium menunjukkan gula darah di atas $200 \mathrm{mg} / \mathrm{dl}$ setelah dilakukan koreksi gula darah diputuskan untuk dilakukan tindakan kraniotomi evakuasi segera dengan pemeriksaan penunjang yang cukup. Tindakan kraniotomi evakuasi pada pasien PIS menjadi tantangan bagi seorang anestesi, sehingga diperlukan pengetahuan akan patofisiologi, mortalitas PIS dan tindakan anestesi yang harus dipersiapkan dan dikerjakan dengan tepat.
\end{abstract}

Kata kunci: hidrosefalus, diabetes mellitus, perdarahan intraserebral

JNI $2022 ; 11(1): 15-23$

\section{Anesthesia Management in Intracerebral Hemorrhage with Hydrocephalus and Diabetes Mellitus}

\begin{abstract}
Intracerebral hemorrhage ( $\mathrm{ICH})$ is the extravasations of blood into the brain parenchyma, which may develop into ventricular and subarachnoid space, there was spontaneous and not caused by trauma (nontraumatic), and one of the most common cause in patients treated in the neurological critical care unit. ICH represents perhaps $10-15 \%$ of all strokes with the highest mortality rates of stroke subtypes and about $60 \%$ of patients with ICH do not survive beyond one year. Case: a man 57 years, came with complaints of loss of consciousness when he just want to eat. On examination of consciousness obtained GCS E1M4V1 with hemodynamic was stable, there left hemiplegic. Patients is intubated and connected with ventilator at Emergency Room Disaster while waiting for result from PCR. From the CT Scan we found 48,93 cc at basal ganglia, capsula externa until lateral periventricle dextra there is a midline distortion $1 \mathrm{~cm}$ to the left. Ventriculomegali with intraventricle hemorrhage wich is fill the lateral ventricle right and left, third ventricular and fourth ventricular. The laboratorium result show the glucose up to $200 \mathrm{mg} / \mathrm{dl}$. After glucose correction, it was decided to evacuate immediately craniotomy action with adequate investigation. Procedure of craniotomy evacuation in $\mathrm{ICH}$ patients be a challenge for an anesthesiologist, so knowledge of the pathophysiology, mortality ICH and anesthetic procedure that should be prepared and done properly.
\end{abstract}

Key words: diabetes mellitus, hydrocephalus, intracerebral hemorrhage

JNI $2022 ; 11(1): 15-23$

This article is licensed under a

Creative Commons Attribution-NonCommercial-ShareAlike 4.0 International License.

CDjefry F Longdong, Iwan Abdul R, Dewi Yulianti B, Sudadi, Siti Shasnak S (2022)

under the CC-BY-NC-SA license 


\section{Pendahuluan}

Perdarahan intraserebral (PIS) baik spontan atau non traumatik adalah ekstravasasi darah yang masuk ke dalam parenkim otak dan dapat berkembang masuk ke ruang ventrikel dan subarachnoid. Hal ini bisa terjadi secara spontan dan bukan akibat trauma. ${ }^{1-4}$ Perdarahan intraserebral adalah salah satu penyebab tersering pada pasien yang di rawat di unit stroke. Angka kematian perdarahan intraserebral masih tinggi. Diperkirakan sekitar $50 \%-60 \%$ dari pasien dengan perdarahan intraserebral tidak bertahan lebih dari 1 tahun dan dikatakan hanya 30\% masih dapat hidup selama 6 bulan setelah kejadian. ${ }^{1-4}$

Insiden perdarahan intraserebral di seluruh dunia adalah 24,6 dalam 100.000 orang per tahun atau kira kira 40.000 sampai 67.000 kasus per tahun. Angka kematian dalam 30 hari berkisar 35\%$52 \%$ dengan hanya $20 \%$ yang kembali berfungsi normal dalam waktu 6 bulan. Biasanya setengah dari kematian terjadi dalam 24 jam pertama. ${ }^{4}$ Hidrosefalus diambil dari bahasa Yunani yang berarti Hydro (air) dan Kephalos (kepala), menggambarkan kelainan lahir dan akumulasi yang berlebihan dari cairan cerebrospinal/ cerebrospinal fluid (CSF) di kepala. Banyak faktor penyebab tetapi yang tersering adalah sumbatan sirkulasi CSF atau gangguan absorpsi. Perdarahan intraserebral yang meluas sampai intraventrikel akan menyebabkan sumbatan pada aliran sirkulasi CSF sehingga terjadi hidrosefalus. ${ }^{5}$ Hidrosefalus sebagai penanda dari hasil yang buruk pada supratentorium perdarahan intraserebral. ${ }^{6}$

Pada orang dewasa dengan perdarahan intraserebral yang meluas hingga intraventrikel terjadi kejadian hidrosephalus lebih dari $67 \%$. Kejadian perdarahan intraserebral yang meluas ke intraventrikel akan menyebabkan sumbatan pada aliran CSF yang akhirnya menyebabkan hidrosefalus. ${ }^{7}$ Beberapa mekanisme terjadinya hidrosefalus setelah terjadinya perdarahan intraserebral dan perdarahan intraventrikel antara lain adalah sumbatan bekuan darah, gangguan barier, inflamasi, komponen darah di mana penyumbatan bekuan darah sering terjadi pada jalan keluar dari ventrikel 4 dan akan menghalangi aliran cairan serebro spinalis, penyumbatan yang terjadi akan menyebabkan peningkatan produksi cairan serebro spinalis, tekanan yang tidak sesuai dan berkurangnya reabsorbsi dari cairan serebro spinalis yang akan merusak sawar darah otak (blood brain barrier), reaksi inflamasi dapat menyebabkan disfungsi granulasi arachnoid dan obstruksi aliran cairan serebrospinal karena fibrotik, produk darah misalnya iron dan thrombin dapat memperparah terjadinya hidrosefalus. ${ }^{8}$ Terdapat hubungan yang erat antara kejadian perdarahan intraserebral dengan diabetes mellitus. Dibandingkan dengan populasi tanpa diabetes mellitus kejadian perdarahan intraserebral lebih tinggi dibandingkan dengan tanpa diabetes mellitus. ${ }^{9-11}$ Level serum glukosa dan diabetes mellitus sebagai penanda adanya perdarahan intraserebral. ${ }^{12-13}$ Telah dibuktikan terjadi kerusakkan pada pembuluh darah kecil di otak (Cerebral Small Vessel Disease/CSVD) pada pasien dengan DM tipe 2. Kerusakan akibat CSVD dilaporkan menjadi penyebab paling tidak $25 \%$ dari seluruh kasus perdarahan intraserebral dan menjadi penyebab terjadinya demensia vaskular. $^{14}$

\section{Kasus}

\section{Anamnesis / Riwayat Penyakit}

Pasien datang dengan keluhan tidak sadar (alloanamnesa dari keluarga), tiba-tiba tidak sadar pada saat mau makan. Penurunan kesadaran sejak 1 jam sebelum masuk RS. Pasien sedang makan bersama teman sambil minum kopi. Sebelumnya mengeluh kepala pusing, mulut terlihat mencong kearah kanan, muntah, kemudian tidak sadarkan diri. Demam tidak ada, batuk tidak ada, 3 hari sebelum masuk RS pasien mengeluh sakit kepala. Riwayat diabetes melllitus positif, minum obat tidak teratur. Riwayat hipertensi tidak ada, buang air besar (BAB)/buang air kecil (BAK) biasa.

\section{Pemeriksaan Fisik}

Pasien tampak sakit berat dengan kesadaran GCS E1 M4 V1 dengan pemeriksaan mata di dapatkan pupil kanan dan kiri isokor dengan diameter 3 $\mathrm{mm}$. Refleks cahaya baik. Hemodinamik dengan tekanan darah 150/90 $\mathrm{mmHg}$, frekuensi nadi 
$96 \mathrm{x} /$ menit, suara jantung baik; murmur tidak ada, suhu $36,8^{\circ} \mathrm{C}$. Pasien sudah terintubasi di IGD Disaster dan tersambung dengan ventilator mode SIMV dengan TV $480 \mathrm{RR} 14 \mathrm{FiO}_{2} 70 \%$ dan saturasi terbaca 97\%. Pada pemeriksaan abdomen tidak ada kelainan. Ekstremitas

Pemeriksaan Penunjang Laboratorium Darah

\begin{tabular}{|c|c|c|c|}
\hline \multicolumn{3}{|l|}{ Darah Rutin } & \multirow[t]{2}{*}{ Nilai normal } \\
\hline Tanggal Pemeriksaan & $22 / 07 / 2020$ & $23 / 07 / 2020$ & \\
\hline $\mathrm{Hb}$ & 12,1 & 10,7 & $12.0-16.0 \mathrm{~g} / \mathrm{dL}$ \\
\hline $\mathrm{Ht}$ & 33 & 29 & $37-47 \%$ \\
\hline Eritrosit & 4,1 & 3,6 & 4.3-6.0 juta/ $\mu \mathrm{L}$ \\
\hline Leukosit & 18950 & 17800 & $4,800-10,800 / \mu \mathrm{L}$ \\
\hline Trombosit & 417 & 343 & $150,000-400,000 / \mu \mathrm{L}$ \\
\hline \multicolumn{4}{|l|}{ Hitung Jenis } \\
\hline Basofil & 0 & 0 & $0-1 \%$ \\
\hline Eosinofil & 0 & 0 & $1-3 \%$ \\
\hline Neutrofil & 88 & 89 & $50-70 \%$ \\
\hline Limfosit & 8 & 6 & $20-40 \%$ \\
\hline Monosit & 4 & 5 & $2-8 \%$ \\
\hline Kimia Klinik & & & Nilai normal \\
\hline SGOT & 21 & 20 & $<35 \mathrm{U} / \mathrm{L}$ \\
\hline SGPT & 16 & 14 & $<40 \mathrm{U} / \mathrm{L}$ \\
\hline Albumin & & 3,1 & $3.5-5.0 \mathrm{~g} / \mathrm{dL}$ \\
\hline Ureum & 51 & 79 & $20-50 \mathrm{mg} / \mathrm{dL}$ \\
\hline GDS & 292 & 190 & $60-100 \mathrm{mg} / \mathrm{dL}$ \\
\hline Natrium & 139 & 142 & $135-147 \mathrm{mmol} / \mathrm{L}$ \\
\hline Kalium & 3,6 & 3,7 & $3.5-5.0 \mathrm{mmol} / \mathrm{L}$ \\
\hline Clorida & 99 & 99 & $95-105 \mathrm{mmol} / \mathrm{L}$ \\
\hline PCR & & Negative & Negative \\
\hline
\end{tabular}

di dapatkan kesan adanya hemiplegi kiri.

Foto Thorax:

- Jantung tidak membesar CTR kurang 50\%

- Aorta elongasi

- Kedua hilus kasar

- Corakan broncho vascular meningkat

- Tidak tampak infiltrat di kedua lapang paru

- Tulang-tulang intak

- Tampak ETT dengan ujung tip di atas karina

Kesan:

Gambaran bronchitis, elongasi Aorta, tidak tampak kelainan radiologis pada jantung, terpasang ETT dengan ujung tip di atas karina.

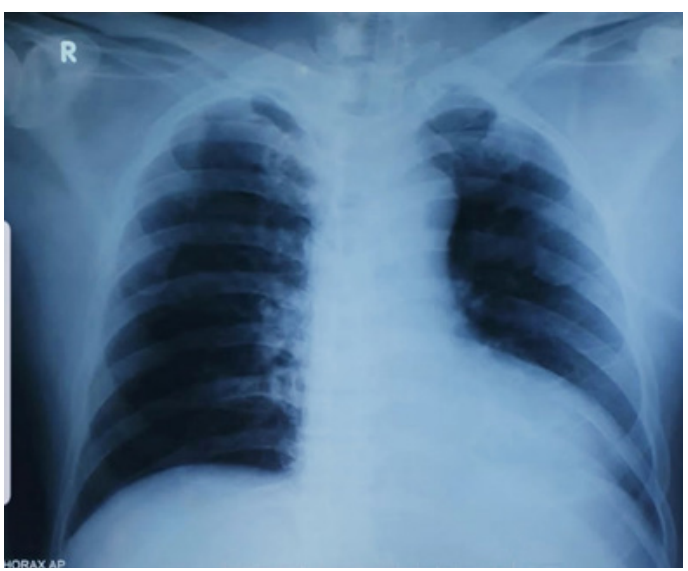

Gambar 1. Foto thoraks

CT Scan kepala pada tanggal 22/07/2020

- Tulang kepala tidak tampak kelainan 


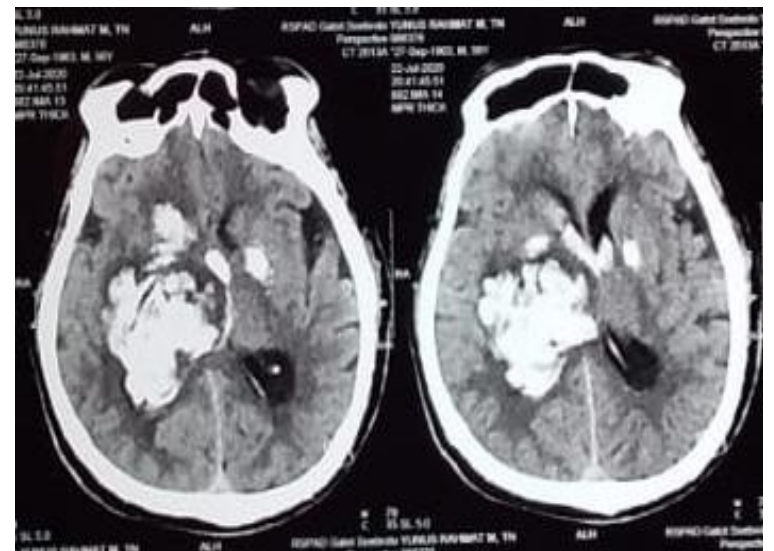

Gambar 2. Hasil CT-Scan

- Orbita dan cavum orbita tidak tampak kelainan

- Os mastoid cerah

- Concha nasalis tidak tampak menebal

- Septum nasi deviasi ke kanan

- Sinus paranasal yang tervisualisasi tampak cerah

- Tampak lesi hiperdens (volume 48,93 cc), batas tegas, tepi irregular di basal ganglia Capsula eksterna sampai paraventrikel lateralis kanan disertai lesi hipodens di sekitarnya

- Sulci di sekitar lesi tampak menyempit

- Fissura Sylvii tampak menyempit

- Tampak lesi hipodens mengisi ventrikel lateralis kiri dan kanan

- Ventrikel lateralis kanan dan kiri, ventrikel 3 dan 4 tampak melebar

- Tampak distorsi midline $1 \mathrm{~cm}$ ke kiri

- Batang otak dan cerebellum tidak tampak kelainan

Kesan:

Perdarahan intracerebral (volume 48,93cc) di basal ganglia, capsula eksterna sampai periventrikel lateralis kanan disertai edema perifocal menyebabkan distorsi midline sejauh 1 $\mathrm{cm}$ ke kiri. Ventrikulomegali disertai perdarahan intraventrikel yang mengisi ventrikel lateralis kanan dan kiri, ventrikel 3 dan ventrikel 4.

\section{Pengelolaan Anestesi}

Jam 13.00 pasien masuk di kamar operasi dengan mobile ventilator, dipasang alat monitor standar dan $\mathrm{ETCO}_{2}$, posisi pasien supine lalu disambungkan dengan ventilator mode volume control dengan respirasi rate 14x/menit dengan volume tidal 500. Minutevolume tercapai6-7Liter/ menit. Setelah sebelumnya diberikan propofol 50 $\mathrm{mg}$, fentanyl $75 \mathrm{mcg}$ dan vecuronium $4 \mathrm{mg}$. Mata diberikan dan ditutup dengan kasa basah yang diplester. Rumatan isoflurane 0,8 sampai $1 \mathrm{MAC}$. Perbandingan oksigen dengan udara ruang 50:50. Dilakukan ventilasi kendali dengan menggunakan vecuronium $3 \mathrm{mg} /$ jam dengan menggunakan continous pump. Dilakukan persiapan operasi dan sebelum dilakukan insisi kulit ditambahkan fentanyl $50 \mathrm{mcg}$. Pada saat dilakukan bor pada tulang tengkorak ditambahkan lagi fentanyl 50 mcg. Diberikan mannitol 20\% dengan dosis 0,5 gram/kgbb dalam 15 menit. Dilakukan operasi eksternal ventrikular drainase. Hemodinamik stabil selama operasi 1 jam 10 menit. Perdarahan sekitar $300 \mathrm{cc}$. Total diuresis $500 \mathrm{cc}$. Cairan yang masuk adalah $500 \mathrm{cc} \mathrm{NaCl} 0,9 \%$ dan $500 \mathrm{cc}$ Ringer Laktat. Sebelum operasi selesai di berikan ondansetron $8 \mathrm{mg}$ intravena. Pasien dipindahkan ke ICU dengan mode ventilator volume control ventilation dengan vecuronium $3 \mathrm{mg} / \mathrm{jam}$, midazolam $3 \mathrm{mg} / \mathrm{jam}$ selama 24 jam. Analgetik postop diberikan tramadol 3x100 mg intravena.

\section{Pengelolaan Pascabedah}

Selama perawatan di ICU hemodinamik dan respirasi stabil. Pada hari ke dua pasien di weaning secara perlahan-lahan. Gula darah di pertahankan di bawah $150 \mathrm{mg} / \mathrm{dl}$ dengan insulin. Untuk menghindari ventilator associated pneumonia karena kemungkinan penggunaan ventilator yang lama, pada hari ke tiga pasien dilakukan

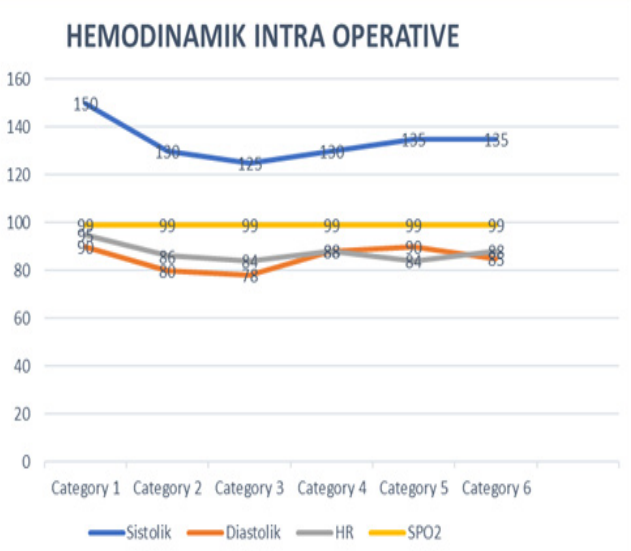

Grafik 1. Hemodinamik Intraoperatif 
Tabel 2.a Pengelolaan Pascabedah di Ruang ICU

\begin{tabular}{|c|c|c|c|}
\hline Hari & Klinis & Laboratorium & Terapi \\
\hline $\mathrm{H}-1$ & $\begin{array}{l}\text { A : terpasang ETT, on vent. } \\
\text { B :on vent mode VC SIMV } \\
\text { PEEP } 5 \text { PS } 10 \text { RR } 15 / 15 \mathrm{x} / \mathrm{mnt} \\
\text { VT } 500 \mathrm{FiO} 290 \% \text { sat } 99 \% \\
\text { C: TD } 135 / 83 \mathrm{mmhg} \mathrm{N} 88 \mathrm{x} / \\
\text { menit. } \\
\text { D : GCS E1M1 Vett on sedasi, } \\
\text { RC }+/+\end{array}$ & $\begin{array}{l}\mathrm{Hb} 11,6 \mathrm{~g} / \mathrm{dL} \\
\text { Hematokrit } 34 \% \\
\text { Trombosit } 268000 / \mathrm{uL} \\
\text { Leukosit } 11000 / \mathrm{uL} \\
\text { PT } 12,3 \text { kontrol 10,9 } \\
\text { APTT } 31,1 \mathrm{kontrol} 23,5 \\
\text { Ddimer } 550 \mathrm{ng} / \mathrm{mL} \\
\text { GDS: } 172 \mathrm{mg} / \mathrm{dL} \\
\text { SGOT/SGPT 38/26 U/L } \\
\text { Ureum/ Creatinin } 20 / 0.58 \mathrm{mg} / \mathrm{dL} \\
\mathrm{Na} / \mathrm{K} / \mathrm{Cl} 135 / 3.5 / 101 \mathrm{mmol} / \mathrm{L}\end{array}$ & $\begin{array}{l}\text { IVFD } \\
\text { Asering } 60 \mathrm{ml} / \text { jam } \\
\text { Dexmedetomidine } 0,3 \mathrm{mcg} / \\
\mathrm{kgBB} / \mathrm{menit} \\
\text { Novorapid }(20 / 20) \sim 1,5 \text { unit / } \\
\text { jam } \\
\text { Inj } \\
\text { Ceftriaxon } 2 \times 2 \text { gram iv } \\
\text { Omeprazole } 1 \text { x40 mg iv } \\
\text { Paracetamol 3x1gr iv } \\
\text { Fenitoin } 3 \times 100 \mathrm{mg} \text { iv } \\
\text { Transamin } 3 \times 500 \mathrm{mg} \text { iv } \\
\text { Vit K 3x10mg iv }\end{array}$ \\
\hline $\mathrm{H}-2$ & $\begin{array}{l}\text { A: terpasang ETT, on vent } \\
\text { B :on vent mode VC SIMV } \\
\text { PEEP } 5 \text { PS } 10 \text { RR 14/16x/mnt } \\
\text { VT } 500 \mathrm{FiO} 260 \% \text { sat } 99 \% \\
\text { C: TD } 130 / 80 \mathrm{mmhg} \text { N } 86 \text { x/ } \\
\text { menit. } \\
\text { D : GCS E2M5VT, RC }+/+\end{array}$ & $\begin{array}{l}\mathrm{Na} 138 \mathrm{mmol} / \mathrm{L} \\
\mathrm{K} 3,3 \mathrm{mmol} / \mathrm{L} \\
\mathrm{Cl} 103 \mathrm{mmol} / \mathrm{L} \\
\mathrm{Ca} 8,5 \mathrm{mg} / \mathrm{dL} \\
\mathrm{Mg} 1,95 \mathrm{mg} / \mathrm{dL} \\
\text { GDS: } 168 \mathrm{mg} / \mathrm{dL}\end{array}$ & $\begin{array}{l}\text { IVFD } \\
\text { Asering } 60 \mathrm{ml} / \mathrm{jam} \\
\text { Miloz }(45 / 45) \sim 3 \mathrm{ml} / \mathrm{jam} \\
\text { Novorapid }(20 / 20) \sim 2 \text { unit / } \\
\text { jam } \\
\text { Inj } \\
\text { Ceftriaxon } 2 \times 2 \text { gram iv } \\
\text { Omeprazole } 1 \text { x40 mg iv } \\
\text { Paracetamol 3x1gr iv } \\
\text { Fenitoin } 3 \times 100 \mathrm{mg} \text { iv } \\
\text { Tramadol 3x100mg iv }\end{array}$ \\
\hline H-3 & $\begin{array}{l}\text { A : on vent, dilakukan } \\
\text { Percutaneous Dilatational } \\
\text { Tracheostomy (PDT) } \\
\text { B :on vent mode VC SIMV } \\
\text { PEEP } 5 \text { PS } 10 \text { RR } 15 / 15 x / m n t \\
\text { VT } 500 \text { FiO2 } 60 \% \text { sat } 99 \% \\
\text { C: TD } 131 / 84 \mathrm{mmhg}, \mathrm{N} 84 \mathrm{x} / \\
\text { menit. } \\
\text { D : GCS E1M1VTC on sedasi, } \\
\text { RC }+/+\end{array}$ & $\begin{array}{l}\mathrm{Na} 139 \mathrm{mmol} / \mathrm{L} \\
\mathrm{K} 3,8 \mathrm{mmol} / \mathrm{L} \\
\mathrm{Cl} 101 \mathrm{mmol} / \mathrm{L} \\
\mathrm{Ca} 8,7 \mathrm{mg} / \mathrm{dL} \\
\mathrm{Mg} 1,9 \mathrm{mg} / \mathrm{dL} \\
\text { PT } 12,5 \mathrm{kontrol} 10,9 \\
\text { APTT } 30,8 \mathrm{kontrol} 23,6 \\
\text { GDS: } 158 \mathrm{mg} / \mathrm{dL}\end{array}$ & $\begin{array}{l}\text { IVFD } \\
\text { Asering } 60 \mathrm{ml} / \mathrm{jam} \\
\text { Miloz }(45 / 45) \sim 3 \mathrm{ml} / \mathrm{jam} \\
\text { Novorapid }(20 / 20) \sim 1,5 \text { unit / } \\
\text { jam } \\
\text { Inj } \\
\text { Ceftriaxon } 2 \times 2 \text { gram iv } \\
\text { Omeprazole } 1 \text { x40 mg iv } \\
\text { Paracetamol 3x1 gr iv } \\
\text { Fenitoin } 3 \times 100 \mathrm{mg} \text { iv } \\
\text { Tramadol 3x100mg }\end{array}$ \\
\hline H-4 & $\begin{array}{l}\text { A : post trakeostomi } 1 \text { hari } \\
\text { yang lalu. } \\
\text { B : on sungkup trakea } 81 \mathrm{pm} \text {, } \\
\text { RR 20x/menit, saturasi } 97 \% \\
\text { C: TD } 130 / 88 \text { mmhg } 88 \mathrm{x} / \\
\text { menit. } \\
\text { D : GCS E2M5Vtc, RC +/+ }\end{array}$ & $\begin{array}{l}\mathrm{Hb} 11,3 \mathrm{~g} / \mathrm{dL} \\
\text { Hematokrit } 33 \% \\
\text { Trombosit } 268000 / \mathrm{uL} \\
\text { Leukosit } 14430 / \mathrm{uL} \\
\text { PT } 11,6 \text { kontrol 11,0 } \\
\text { APTT } 26,6 \mathrm{kontrol} 23,5 \\
\text { Ddimer } 550 \mathrm{ng} / \mathrm{mL} \\
\text { Albumin } 3,6 \mathrm{~g} / \mathrm{dL} \\
\text { Ureum } 51 \mathrm{mg} / \mathrm{dL} \\
\text { Creatinin } 0.63 \mathrm{mg} / \mathrm{dL} \\
\text { Na/K/Cl } 140 / 3.5 / 105 \mathrm{mmol} / \mathrm{L} \\
\text { Procalcitonin } 0,37 \mathrm{ug} / \mathrm{L} \\
\end{array}$ & $\begin{array}{l}\text { IVFD } \\
\text { Asering } 60 \mathrm{ml} / \text { jam } \\
\text { Inj } \\
\text { Ceftriaxon } 2 \times 2 \text { gram iv } \\
\text { Omeprazole } 1 \times 40 \mathrm{mg} \text { iv } \\
\text { Paracetamol } 3 \times 1 \mathrm{gr} \text { iv } \\
\text { Fenitoin } 3 \times 100 \mathrm{mgiv} \\
\text { Levemir } 1 \times 10 \text { unit sc } \\
\text { Novorapid 3x6unit sc }\end{array}$ \\
\hline
\end{tabular}


Tabel 2.b Pengelolaan Pascabedah di Ruang ICU

\begin{tabular}{|c|c|c|c|}
\hline Hari & Klinis & Laboratorium & Terapi \\
\hline H-5 & $\begin{array}{l}\text { A: kontak }(+) \\
\text { B : on sungkup trakea } \\
6 \text { lpm, RR } 20 x / \text { menit, } \\
\text { saturasi } 99 \% \\
\text { C: TD } 132 / 79 \text { mmhg N } \\
77 \text { x/menit. } \\
\text { D : GCS E3M5Vtc, RC } \\
+/+\end{array}$ & $\begin{array}{l}\mathrm{Na} 138 \mathrm{mmol} / \mathrm{L} \\
\mathrm{K} 4,0 \mathrm{mmol} / \mathrm{L} \\
\mathrm{Cl} 104 \mathrm{mmol} / \mathrm{L} \\
\mathrm{Ca} 8,5 \mathrm{mg} / \mathrm{dL} \\
\mathrm{Mg} 1,88 \mathrm{mg} / \mathrm{dL}\end{array}$ & $\begin{array}{l}\text { IVFD } \\
\text { Asering } 60 \mathrm{ml} / \mathrm{jam} \\
\text { Inj } \\
\text { Ceftriaxon } 2 \times 2 \text { gram iv } \\
\text { Omeprazole } 1 \text { x40 mg iv } \\
\text { Paracetamol } 3 \times 1 \mathrm{gr} \text { iv } \\
\text { Fenitoin } 3 \times 100 \mathrm{mg} \text { iv } \\
\text { Levemir } 1 \times 10 \text { unit sc } \\
\text { Novorapid } 3 \times 6 \text { unit sc } \\
\text { Pasien pindah stroke unit }\end{array}$ \\
\hline
\end{tabular}

trakeostomi non surgical atau percutaneus dilatational tracheostomy (PDT). GCS meningkat menjadi E2 M5 V2. Pada hari keempat di ICU karena respirasi yang membaik, ventilator diganti dengan sungkup PDT dengan oksigen $6 \mathrm{~L} /$ menit dan saturasi terbaca $97 \%$. Selama perawatan di ICU hemodinamik stabil dan pada hari ke 5 pasien pindah ke ruang stroke unit

\section{Pembahasan}

Perdarahan intraserebral (PIS) mengenai $\geq$ 1 juta penduduk di seluruh dunia pertahun dan sangat mematikan dan merupakan tipe stroke yang sangat merusak. Hipertensi tak terkontrol merupakan faktor risiko yang paling sering menyebabkan PIS. ${ }^{15}$ Perdarahan spontan intraserebral didefinisikan sebagai perdarahan intraparenkim yang bukan dikarenakan oleh trauma atau operasi. Faktor risiko yang paling sering adalah hipertensi, umur, riwayat penyalahgunaan alkohol, metamfetamin atau kokain. ${ }^{15}$ Beberapa penelitian mengatakan bahwa hipertensi meningkatkan resiko terjadinya perdarahan intraserebral lebih dari dua kali lipat, terutama pada pasien kurang dari 55 tahun yang menghentikan pengobatan anti hipertensinya.

Perdarahan intraserebral spontan dapat digolongkan sebagai primer dan sekunder tergantung dari penyakit penyerta. Perdarahan intraserebral (PIS) primer yang terjadi pada 70 sampai 80 kasus disebabkan oleh ruptur spontan dari pembuluh darah kecil yang diakibatkan oleh hipertensi dan amyloid angiopaty. Perdarahan intraserebral sekunder berhubungan dengan keadaan kongenital dan acquired condition contohnya malformasi vaskuler, tumor, gangguan koagulasi, penggunaan antikoagulan dan trombolitik, serebral vasculitis, penyalahgunaan obat dan thrombosis vena serebral. ${ }^{15}$ Perdarahan intraserebral dapat diduga pada pasien dengan sakit kepala yang berat, muntah, peningkatan tekanan sistolik dan menurunnya kesadaran. Diagnosa yang cepat merupakan hal yang sangat menentukan untuk mendapatkan hasil yang baik. Perburukan yang cepat pada beberapa jam pertama merupakan suatu hal yang sering terjadi pada ekspansi hematom. Cepatnya perubahan neurologis dan hilangnya kesadaran akan menyebabkan gangguan pada refleks untuk mempertahankan jalan nafas. Kegagalan dalam

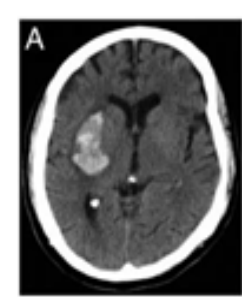

Putamen

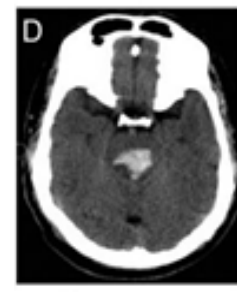

Pons

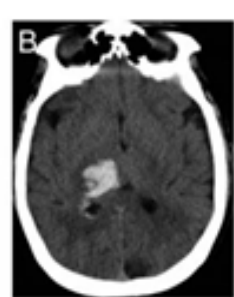

Thalamus

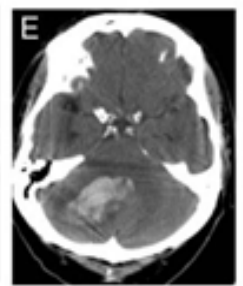

Cerebellum

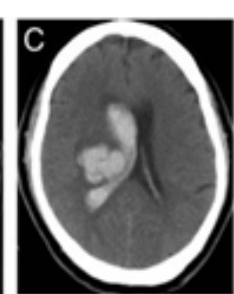

Subcortical

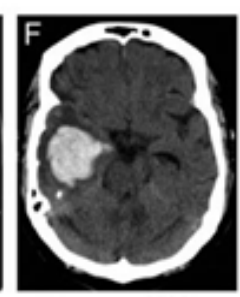

Temporal lobe
Gambar 3. Lokasi Tipikal Perdarahan

Intraserebral. ${ }^{15}$ 
mempertahankan jalan nafas ini mengakibatkan komplikasi seperti terjadinya aspirasi, hipoksemia dan hiperkarbia. Untuk mengatasi keadaan ini dibutuhkan suatu tindakkan untuk menjaga jalan nafas dengan melakukan pemasangan pipa endotrakheal (endo tracheal tube/ETT) dengan menggunakan tehnik rapid sequence induction. Pada pasien dengan tekanan intrakranial yang meningkat dipertimbangkan pemberian premedikasi dengan lidokain intravena pada tindakan rapid sequence induction. Target utama pada penatalaksanaan anestesi pada pasien cedera kepala adalah menjamin cerebral perfusion pressure (CPP) yang adekuat sehingga kebutuhan metabolik regional terpenuhi dan otak yang relaks serta tidak bengkak. Jika obat anestesi atau teknik anestesi tidak di gunakan dengan benar maka akan memperburuk kondisi patologis intrakranial yang ada dan dapat menimbulkan kerusakan baru.

Pada pasien dengan cedera kepala terjadi kerusakan pada sistem autoregulasi cerebral blood flow (CBF) maka CBF yang di proyeksikan sebagai cerebral perfusion pressure akan di tentukan oleh tekanan arteri rerata (MAP) dan tekanan intrakranial (ICP) dengan memakai rumus $\mathrm{CPP}=\mathrm{MAP}-\mathrm{ICP} .{ }^{19}$ Sesuai dengan terget di atas maka monitoring secara ketat parameter hemodinamik berupa tekanan darah dan laju nadi mutlak di laksanakan pada saat praoperasi, selama operasi dan pasca operasi di ruang perawatan intensif. Cara yang dilakukan adalah mempertahankan CPP menjamin MAP yang adekuat dengan menggunakan cairan atau vasopresor serta mencegah peningkatan ICP yang berlebihan. Nilai normal dari CPP adalah $60-80 \mathrm{mmHg}$. Terapi untuk menurunkan ICP pada level 20-25 mmHg bertujuan untuk mempertahankan CPP $>70 \mathrm{mmHg} .{ }^{19}$ Berdasarkan beberapa penelitian terdapat hubungan yang erat antara perdarahan intraserebral dengan diabetes mellitus karena hasil angka kejadian PIS yang tinggi pada populasi penderita diabetes mellitus. ${ }^{9-11}$ Serum glukosa level dan diabetes mellitus sebagai penanda perdarahan intraserebral dan akut iskemik stroke. ${ }^{12}$ Hidrosefalus adalah menggambarkan kelainan lahir dan akumulasi yang berlebihan dari cairan serebrospinal/ cerebrospinal fluid (CSF) di kepala. Banyak faktor penyebab tetapi yang tersering adalah sumbatan sirkulasi CSF atau gangguan absorpsi. Perdarahan intraserebral yang meluas sampai intraventrikel akan menyebabkan sumbatan pada aliran sirkulasi CSF sehingga terjadi hidrosefalus. ${ }^{5}$ Pada pasien ini ditemukan perdarahan sampai intraventrikel yang akan menyebabkan gangguan pada aliran CSF, terjadinya peradangan serta terjadi hasil produksi darah akibat perdarahan yaitu iron dan thrombin yang akan memperparah terjadinya sumbatan di jalan keluar cairan serebrospinalis di ventrikel 4 yang akan menyebabkan terjadinya hidrosefalus non komunikans yang terlihat jelas pada CT-scan. ${ }^{8}$ Hidrosefalus merupakan salah satu prediktor untuk menentukan luaran yang buruk dari suatu perdarahan supratentorium intraserebral. ${ }^{16}$

Penggunaan CT- scan kepala yang luas secara dramatis memberikan perubahan dalam pendekatan diagnostik pada penyakit ini. CTscan menjadi pemeriksaan penunjang yang utama dalam mengevaluasi PIS. Evaluasi yang dilakukan adalah mengenai ukuran dan lokasi dari hematom, penyebaran ke sistem ventrikel, derajat edema dan kerusakkan secara anatomis. ${ }^{17}$ CT-angiografi mutlak dilakukan pada pasien dengan PIS sekunder seperti kemungkinan adanya aneurisma, malformasi arteri vena, trombus di sinus duramater atau vena kortikal. ${ }^{17}$ Hiperglikemi atau diabetes melitus adalah suatu penanda yang penting dalam 30 hari pada pasien diabetik atau non diabetik dengan PIS. Efek yang merusak dari hiperglikemi dapat terjadi pada sindrom vaskuler yang akut. Pada kejadian stroke iskemik terjadi kejadian hiperglikemik 20\%$40 \%$ dari pasien dan ini dihubungkan dengan infark yang meluas, luaran fungsional yang buruk, hospitalisasi yang lama, tingginya biaya perawatan dan meningkatnya resiko kematian. ${ }^{15}$ Tindakan yang dilakukan pada pasien ini adalah terapi pembedahan. Tindakan pembedahan dapat berupa pemasangan drainase ventrikel eksternal ataupun dengan tindakan kraniotomi untuk mengevakuasi perdarahan. Namun tidak semua pasien PIS harus di operasi contohnya pasien PIS dengan perdarahan yang sedikit (volume $10-20$ cc), atau defisit neurologis yang minimal dan pasien dengan GCS $\leq 4$. Rentang skor PIS adalah 
Tabel 3. Skor PIS 18

\begin{tabular}{lll}
\hline \multicolumn{1}{c}{ Komponen } & & Skor \\
\hline GCS & $3-4$ & 2 \\
& $5-12$ & 1 \\
& $13-14$ & 0 \\
Volume PIC (cm3) & $\geq 30$ & 1 \\
& $<30$ & 0 \\
IVH & Ya & 1 \\
Infratentorial PIS & Ya & 1 \\
& Tidak & 0 \\
Umur (tahun) & $\geq 80$ & 1 \\
& $<80$ & 0 \\
\hline
\end{tabular}

Keterangan :

1. GCS = Glasgow Com a Scale; PIC = perdarahan intracerebral; IVH = intraventricular hemorrhage

2. Interpretasi skor berdasarkan 30 days mortality : $0=$ $0 \% ; 1=13 \% ; 2=26 \% ; 3=72 \% ; 4=97 \% ; 5=100 \%$; $6=100 \%$

$0-5$. Tidak ada pasien dengan skor PIS 0 yang meninggal. Sedangkan semua pasien dengan skor PIS lebih dari 5 akan meninggal. Dalam 30 hari tingkat kematian pasien PIS dengan skor 1,2, 3 dan 4 adalah $13 \%, 26 \%, 72 \%$ dan $97 \%$. Pada pasien ini didapatkan PIS skor dengan jumlah 3 dengan angka kematian dalam 30 hari sebesar $72 \%$.

\section{Simpulan}

Perdarahan intraserebral merupakan penyakit yang fatal dengan sejumlah faktor yang mempengaruhi terhadap luaran klinis dan gejala sisa. Terdapat hubungan yang erat antara PIS, hidrosefalus dan diabetes mellitus yang mana dengan adanya PIS dan intraventrikel akan menyebabkan terjadinya bekuan darah dan kerusakan barrier serta inflamasi yang akan menyebabkan terjadinya hidrosefalus non komunikans dan dengan adanya cerebro small vessel desease (CSVD) pada pasien diabetes mellitus yang dapat menyebabkan kerapuhan pada pembuluh darah sehingga mudah terjadi perdarahan. Target utama pada penatalaksanaan anestesi pada pasien cedera kepala adalah menjamin CPP yang adekuat sehingga kebutuhan metabolik regional terpenuhi dan otak yang relaks serta tidak bengkak. Dengan menjaga CPP pada nilai yang normal yaitu sekitar $60-80 \mathrm{mmHg}$ maka kebutuhan kebutuhan metabolik otak akan terpenuhi. Penting sekali memahami secara teliti semua aspek penyakit ini dan kemungkinan komplikasi yang akan didapatkan sehubungan dengan tindakan anestesi yang dilakukan oleh spesialis anestesiologi. Dengan mengetahui semua aspek tentang penyakit ini kita akan meminimalkan kerusakan saraf, mencegah dan mengobati komplikasi yang terjadi, mempercepat pemulihan dan mencegah kekambuhan.

\section{Daftar Pustaka}

1. Feen ES, Lavery AW, Suarez JI. Management of nontraumatic intracerebral hemorrhage. Dalam: Suarez JI, Tarsy D, eds. Critical Care Neurology and Neurosurgery. NewJersey: Humana Press; 2004, 353-64.

2. Manoach S, Charchaflieh JG. Traumatic brain injury, stroke and brain death. Dalam: Newfield P, Cottrell J, eds. Handbook of Neuroanesthesia, 4th edition. Philadelphia: Lippincott Williams \& Wilkins; 2007, 43244.

3. Stoelting RK, Dierdorf SF. Anesthesia and CoExisting Disease, 4th edition, Philadelphia: Churchill Livingstone; 2002, 160-1

4. Caceres JA, Goldstein J. Intracranial hemorrhage emergency. Med Clin N Am 2012: 771--94

5. Krovvidi H, Flint G, William AV. Perioperative management of hydrocephalus. BJA Education 2018; 18(5):140-6

6. Stein $M$, Luecke $M$, Preuss $M$, Boeker DK, Joedicke A, Oertel MF. Spontaneous intracerebral haemorrhage with ventricular extension and the grading of obstructive hydrocephalus: the prediction of outcome of a special life threatening entity. neurosurgeryonline.com, 2010 vol 67, 1243-51.

7. Strahle J, Garton HJL, Maher CO, Muraszko K.M, Keep R.F, Xi Guohua. Mechanism of hydrocephalus after neonatal and adult 
intraventricular haemorrhage. Transl.stroke Res.2012;3(suppl1):25-38.

8. Bu Y, Chen M, Gao T, Wang X, Li X, Gao F. Mechanisms of hydrocephalus after intraventricular haemorrhage in adult. Stroke and Vascular Neurology 2016:23-7.

9. Boulanger M, Ponn MTC. Association between diabetes mellitus and the occurrence and outcome of intracerebral hemorrhage. American academy of neurology 2016;87(9):870-78.

10. Boulanger M, Salman RA, Kerssens WSH. Association between diabetes mellitus and incidence and case fatality after stroke due intracerebral hemorrhage: a retrospective population-based cohort study. Diabetes, Obesity and metabolism 2017; 19(8).

11. Herzig R, Vlachova J, Mares M, Gabrys D, Sanak D, Skoloudik D, et al. Occurrence of diabetes mellitus in spontaneous intracerebral hemorrhage. Acta diabetol 2007; 44: 201-7.

12. Demchuck AM, Morgensten LB, Krieger DW, Chi TL, Hu W, Wein TH, et al. Serum glucose level and diabetes predict tissue plasminogen activator-related intracerebral haemorrhage in acute ischemic stroke. Stroke.ahajournal.1999; 30:34-39.

13. Tetri S, Juvela S, Saloheimo P, Pyhtinen J, Hillbom M. Hypertension and diabetes predictor of early death spontan intracerebral haemorrhage. J Neurosurg 2009; 110:411417,1-7.

14. Liu J, Rutten-Jacobs L, Liu M, Marcus H.S, Traylor M. Causal impact of type 2 diabetes mellitus on cerebral small vessel disease. Stroke.ahajournals.org 2018:1-23.

15. Dastur CK, Yu W. Current management of spontaneous intracerebral haemorrhage. Stroke and vascular neurology 2017: 21-9.

16. Diringer MN, Edward DF, Zazulia AR. Hydrocephalus a previously unrecognized predictor of poor outcome from supratentorial intracerebral haemorrhage. Stroke.ahajournal 1998:1-7.

17. Rincon F, Mayer SA. Review clinical review: Critical care management of spontaneous intracerebral haemorrhage. Critical Care 2008;12(6):237-52.

18. Hemphill JC, Bonovich DC, Besmertis L,Manley GT, Johnston SC, Tuhrim S. The ICH score: a simple, reliable grading scale for intracerebral. Stroke. 2001; 32: 891-7.

19. Sakabe T, Matsumoto M. Effects of anesthetic agents and other drugs on cerebral blood flow, metabolism, and intracranial pressure. Dalam: Cottrell JE, Young WL, eds. Cottrell and Younges Neuroanesthesia. Philadelphia: Mosby Elsevier; 2010,78-94. 